\title{
Vitamin D3 potentiates the antitumorigenic effects of arsenic trioxide in human leukemia $(\mathrm{HL}-60)$ cells
}

\author{
Christian S Rogers, Clement G Yedjou, Dwayne J Sutton and Paul B Tchounwou*
}

\begin{abstract}
Background: Arsenic trioxide (ATO) is a novel form of therapy that has been found to aid acute promyelocytic leukemia (APL) patients. Our laboratory has demonstrated that ATO-induced cytotoxicity in human leukemia (HL-60) cells is mediated by oxidative stress. Pro-oxidants have been known to play a role in free radical-mediated oxidative stress. Vitamin $D_{3}$, (Vit $\left.D_{3}\right)$ an active metabolite of vitamin $D$ has been reported to inhibit the growth of number neoplasms such as prostate, breast, colorectal, leukemia, and skin cancers. The goal of the present research was to use (HL-60) cells as an in vitro test model to evaluate whether low doses of Vit $D_{3}$ potentiate the toxicity of ATO and whether this toxic action is mediated via apoptotic mechanisms.
\end{abstract}

Method: HL-60 cells were treated either with a pharmacologic dose of ATO alone and with several low doses of Vit $D_{3}$. Cell survival was determined by MTT assay. Cell apoptosis was measured both by flow cytometry assessment, and DNA laddering assay.

Results: MTT assay indicated that Vit $\mathrm{D}_{3}$ co-treatment potentiates ATO toxicity in HL-60 cells in a dose dependent manner. A statistically significant and dose-dependent increase $(p<0.05)$ was recorded in annexin $V$ positive cells (apoptotic cells) with increasing doses of Vit $\mathrm{D}_{3}$ in ATO-treated cells. This finding was confirmed by the result of DNA laddering assay showing clear evidence of nucleosomal DNA fragmentation in vitamin and ATO co-treated cells.

Conclusion: The present study indicates that Vit $D_{3}$ potentiates the antitumor effects of ATO. This potentiation is mediated at least in part, through induction of phosphatidylserine externalization and nucleosomal DNA fragmentation. These findings highlight the potential impact of Vit $D_{3}$ in promoting the pharmacological effect of ATO, suggesting a possible future role of Vit $\mathrm{D}_{3} / \mathrm{ATO}$ combination therapy in patients with acute promyelocytic leukemia (APL).

Keywords: Vitamin D3, Arsenic trioxide, Cytotoxicity, Apoptosis, HL-60 cells

\section{Background}

Acute promyelocytic leukemia (APL) is a subtype of the acute myeloid leukemia (AML). APL is characterized by abnormal, heavily granulated promyelocytes, a form of white blood cells. APL results in the accumulation of these atypical promyelocytes in the bone marrow and peripheral blood, and replaces normal blood cells. The standard treatment of this disease is chemotherapy and all trans-retinoic acid. Interestingly, arsenic trioxide (ATO) is a new form of therapy that has been found to benefit APL patients. Both in vitro and in vivo studies

\footnotetext{
* Correspondence: paul.b.tchjounwou@jsums.edu

Environmental Toxicology Research Laboratory, NIH-Center for Environmental Health College of Science, Engineering and Technology, Jackson State University, 1400 Lynch Street, Box 18540, Jackson, MS 39217, USA
}

have shown that ATO can induce clinical remission of de novo and relapsed APL patients [1,2]. Several studies have reported that ATO induces apoptosis in malignant cells including APL, non-Hodgkin's lymphoma, multiple myeloma, and chronic lymphocytic leukemia cells [3-5]. Also, ATO has been found to induce apoptosis in myeloid leukemia cells such as U937 and KG-1 cells [6]. ATO induced apoptosis is associated with the generation of reactive oxygen species that contribute significantly to cell killing [7-9] and inhibition of growth [10].

Vitamin D was discovered by Edward Mellanby in 1919 during his classic experiments with rickets [11]. It is classified into five forms including vitamin $\mathrm{D}_{2}$ (ergosterol); vitamin $\mathrm{D}_{3}$ (cholecalciferol); vitamin $\mathrm{D}_{4}$ (22, 23 
dihydroergoalciferol); vitamin $\mathrm{D}_{5}$ (sitosterol [24-ethylcholecal- ciferol]); and vitamin $\mathrm{D}_{6}$ (stigmasterol) [12]. Vitamin $\mathrm{D}$ influences almost every cell in the body, and it is one of nature's most potent cancer fighting agents. The receptors that respond to Vitamin D convert it to calcitrol which is a hormone. The Body organs use calcitol to repair damage and eradicate cancer cells. Experimental studies have shown that vitamin $\mathrm{D}$ is able to enter cancer cells and trigger apoptosis or cancer cell death. It is as effective at killing cancer cells in a way similar to the cancer drug Tamoxifen, and without the side effects.

A preclinical study indicated that exposing cancer cells and vascular endothelial cells to high concentrations of active metabolites of Vit $\mathrm{D}_{3}$ halts progression through growth arrest, apoptosis and cell cycle arrest in vivo [13]. Vit $D_{3}$ potentiates the antitumor activity of a number of types of cytotoxic anticancer agents in in vivo preclinical models. Vit $\mathrm{D}_{3}$ analogues initiate signaling through a number of important pathways, but the pathway essential to the antitumor activities of Vit $\mathrm{D}_{3}$ are unclear [14]. Since both ATO and Vit $\mathrm{D}_{3}$ have been found to induce apoptosis in a variety of cancer cells, we designed this present study to evaluate the combined effect of both compounds. Also the mechanisms of action of $\mathrm{VitD}_{3}$ in combination with ATO for the treatment of APL remain largely unknown. Therefore, the aim of this research was to use human leukemia (HL-60) APL-cells as an in vitro test model to determine the potential mechanism of action of $\mathrm{VitD}_{3}$ on ATO chemotherapy of APL.

\section{Results}

Vitamin D3 potentiates the cytotoxicity of arsenic trioxide in HL-60 cells

We have previously reported that physiologic doses of ATO increase cellular proliferation while pharmacologic doses of ATO were highly cytotoxic to HL-60 cells, showing a $24 \mathrm{hr} \mathrm{LD}_{50}$ of $6.4 \pm 0.6 \mu \mathrm{g} / \mathrm{mL}$ [15]. As shown in (Figure 1), a single pharmacologic dose $(6 \mu \mathrm{g} / \mathrm{mL})$ of ATO is highly cytotoxic to HL-60 cells. Low doses of Vit $\mathrm{D}_{3}$ have no effects on cell growth while on the other hand high doses inhibit the growth of HL-60 cells and cause significant cell death. Low doses of Vit $\mathrm{D}_{3}$ were selected based on the data generated from the MTT assay (Figure 2). Co-treatment of these cells using low doses $(0.5-1.5 \mu \mathrm{M})$ of $\mathrm{Vit} \mathrm{D}_{3}$ and a pharmacologic dose $(6 \mu \mathrm{g} / \mathrm{mL})$ of ATO resulted in a higher level of cell death than did ATO alone. We found that the viability of HL-60 cells declined from $(62 \pm 5) \%$ in cells treated with ATO alone to $(44 \pm 3) \%$ in cells co-treated with $1.5 \mu \mathrm{M}$ Vit $\mathrm{D}_{3}$ and $6 \mu \mathrm{g} / \mathrm{mL}$ ATO with $P<0.05$ (Figure 3).

\section{Vitamin D3 potentiates arsenic trioxide-induced apoptosis in HL-60 cells}

To determine whether low doses of $\mathrm{VitD}_{3}$ could sensitize arsenic trioxide (ATO)-mediated apoptosis, HL-60 cells were treated for $24 \mathrm{hr}$, subsequently stained with annexin V/PI, and analyzed by flow cytometry. As shown in (Figures 4 and 5 ), Vit $\mathrm{D}_{3}$ enhances the proportion of cells undergoing apoptosis in ATO-treated cells compared to ATO alone. For example, the proportion of annexin $\mathrm{V}$ positive was $(38 \pm 5) \%$ in cells treated with $6 \mu \mathrm{g} / \mathrm{mL}$ ATO alone and $(57 \pm 6) \%$ in cells treated with $1.5 \mu \mathrm{M}$ Vit $\mathrm{D}_{3}$ plus $6 \mu \mathrm{g} / \mathrm{mL}$ ATO with $\mathrm{P}<0.05$.

\section{Vitamin D3 potentiates arsenic trioxide-induced nucleosomal DNA fragmentation in HL-60 cells}

In this study, we used camptothecin (CAM) as a positive control for DNA fragmentation because it is potent inhibitor of topoisomerase I and induces DNA fragmentation in a dose-dependent manner. Our results demonstrated

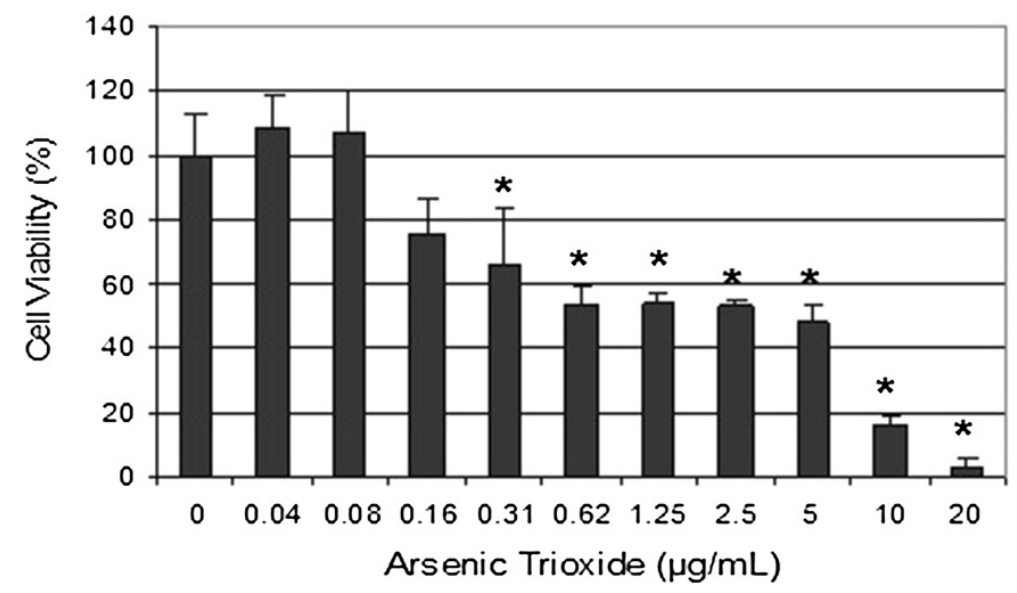

Figure 1 Toxicity of arsenic trioxide to human leukemia (HL-60) cells. HL-60 cells were cultured with different doses of arsenic trioxide for $24 \mathrm{hr}$ as indicated in the Materials and Methods. Cell viability was determined based on the MTT assay. Each point represents a mean \pm SD of 3 experiments with 6 replicates per dose. *Significantly different $(p<0.05)$ from the control, according to the Dunnett's test [15]. 


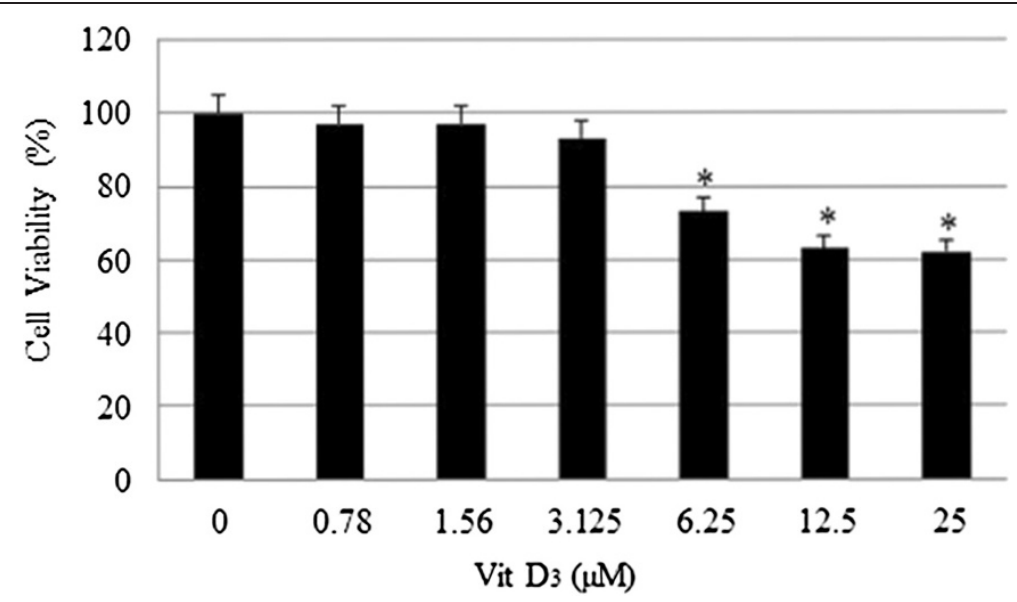

Figure 2 Effect of vitamin $D_{3}\left(\right.$ Vit $\left.D_{3}\right)$ on human leukemia (HL-60) cells. HL-60 cells were cultured with different doses of Vit $D_{3}$ for 24 hr as indicated in the Materials and Methods. Cell viability was determined based on the MTT assay. Each point represents a mean value and standard deviation of 3 experiments with 6 replicates per dose. *Significantly different $(p<0.05)$ from the control, according to the Dunnett's test.

positive DNA fragmentation with $6 \mu \mathrm{g} / \mathrm{mL}$ ATO alone and Vit $\mathrm{D}_{3}$ concentrations of $(0.5,1.0,1.5 \mu \mathrm{M})$ and $6 \mu \mathrm{g} / \mathrm{mL}$ ATO combined, upon 24-hr incubation with HL-60 cells. As seen in the dose-response experiments of the present study, the extent of DNA fragmentation increased proportionately with increasing doses of Vit $\mathrm{D}_{3}$, suggesting that Vit $\mathrm{D}_{3}$ potentiates ATO induced apoptosis in HL-60 cells in a dose-dependent manner (Figure 6).

\section{Discussion}

Several experimental studies have suggested a possible association between vitamin $\mathrm{D}$ and cancer risk reduction. For instance, in vitro and in vivo studies with cancer cells and tumors in mice found that vitamin D has several activities that might slow and/or prevent the development of cancer, including promoting cellular differentiation, decreasing cancer cell growth, stimulating cell death, and reducing tumor blood vessel formation [16-18].

Arsenic trioxide (ATO) has previously been reported to be cytotoxic to various mammalian cancer cell lines $[10,19]$. Data obtained from the present study indicate that the combination of low doses of vitamin $\mathrm{D}_{3}$ plus a pharmacologic dose of ATO is more cytotoxic to human promyelocytic leukemia (HL-60) cells compared to ATO alone. We found that Vit $\mathrm{D}_{3}$ co-treatment enhances ATO toxicity in HL-60 cells in a dose dependent manner. Consistent with the present study, previous by published reports from our laboratory demonstrated that

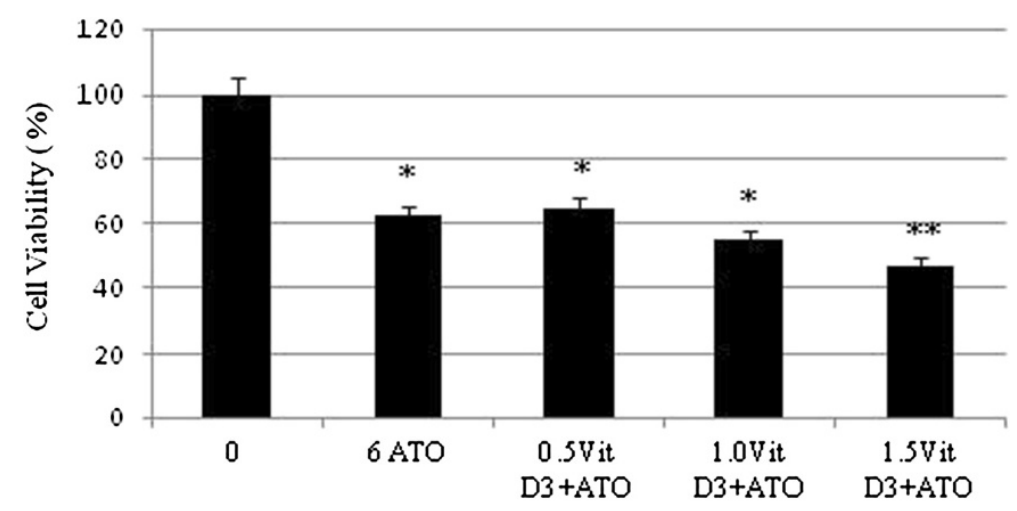

Vit D3 $=$ Vitamin D3 $(\mu \mathrm{M})+\mathrm{ATO}=$ Arsenic Trioxide

Figure 3 Cytotoxic effect of VitD $_{3}$ and ATO combination treatment on human leukemia (HL-60) cells. HL-60 cells were cultured in the absence or presence of vitD3 and ATO or in combination of VitD $\mathrm{D}_{3}$ and ATO for $24 \mathrm{hr}$ as indicated in the Materials and Methods. Cell viability was determined based on the MTT assay. Each point represents a mean value and standard deviation of 3 experiments with 6 replicates per dose. *Significantly different from the control by ANOVA Dunnett's test; $p<0.05$. * Significantly different from ATO alone by ANOVA Dunnett's test; $p<0.05$. 

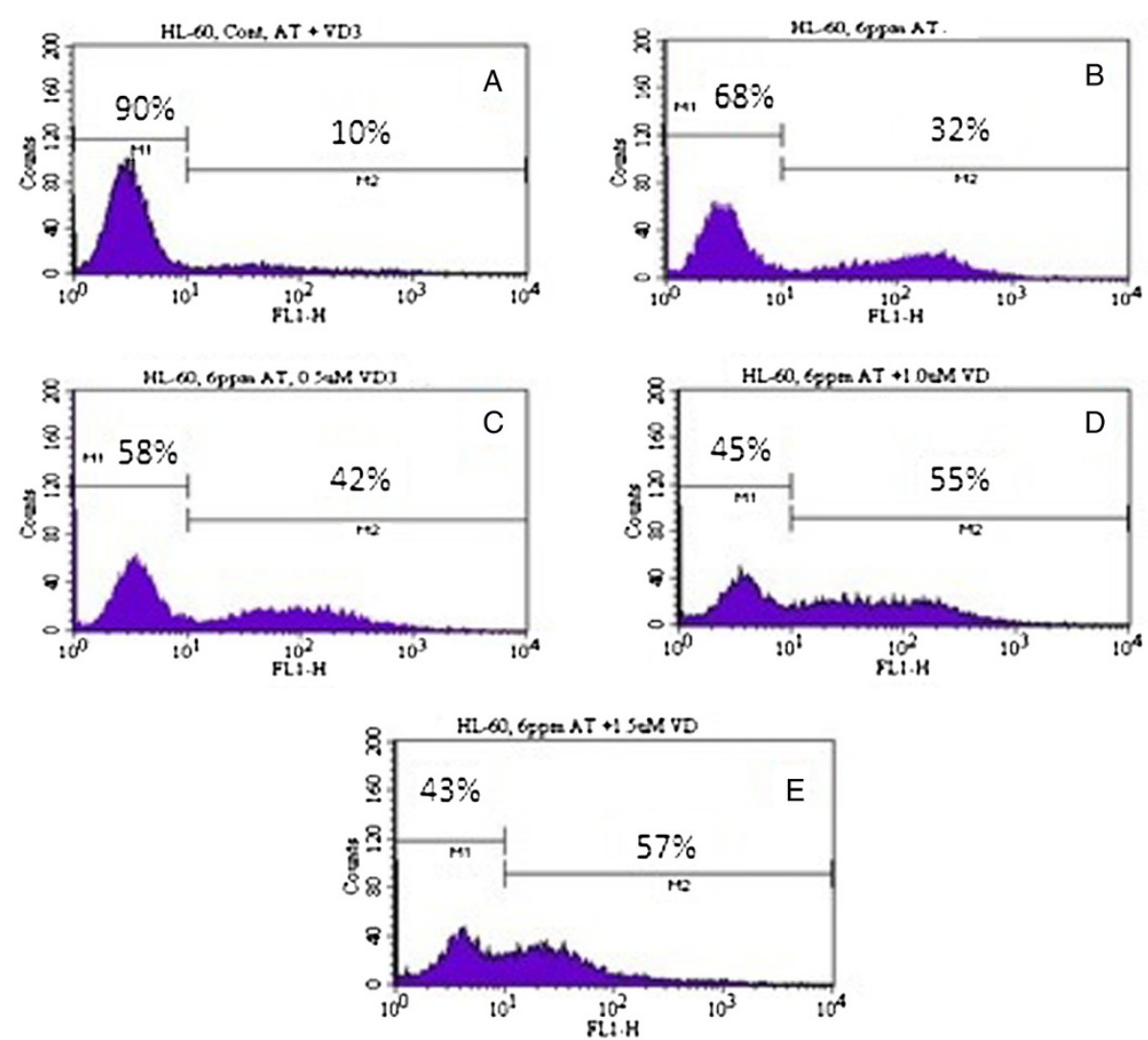

Figure 4 Representative flow cytometry analysis data from Annexin V-FITC staining. The histogram shows a comparison of the distribution of negative annexin $V$ cells (M1) and positive annexin $V$ cells (M2) after $24 \mathrm{hr}$ incubation in HL-60 cells. $A=$ control; $B=6 \mu \mathrm{g} / \mathrm{mL} \mathrm{ATO;C}=0.5 \mu \mathrm{M}$ $V_{i t D}+6 \mu \mathrm{g} / \mathrm{mL}$ ATO; $\mathrm{D}=1.0 \mu \mathrm{MVitD}{ }_{3}+6 \mu \mathrm{g} / \mathrm{mL}$ ATO; $\mathrm{E}=1.5 \mu \mathrm{MVitD}{ }_{3} 6 \mu \mathrm{g} / \mathrm{mL}$ ATO.

ascorbic acid increases the activity of ATO in leukemia cells [20]. High doses of Vit $\mathrm{D}_{3}$ treatment alone prove to be cytotoxic, suggesting that it has the potential to be an enabling agent that sensitizes tumor cells to the cytotoxic effect of ATO-based chemotherapy. Vit $\mathrm{D}_{3}$ has been found to play an important role in controlling calcium homeostasis and bone metabolism [21,22] and in preventing diabetes [23]. Vit $\mathrm{D}_{3}$ induces monocytic differentiation in human myeloid leukemia cells including HL-60 myeloblastic cells [24].

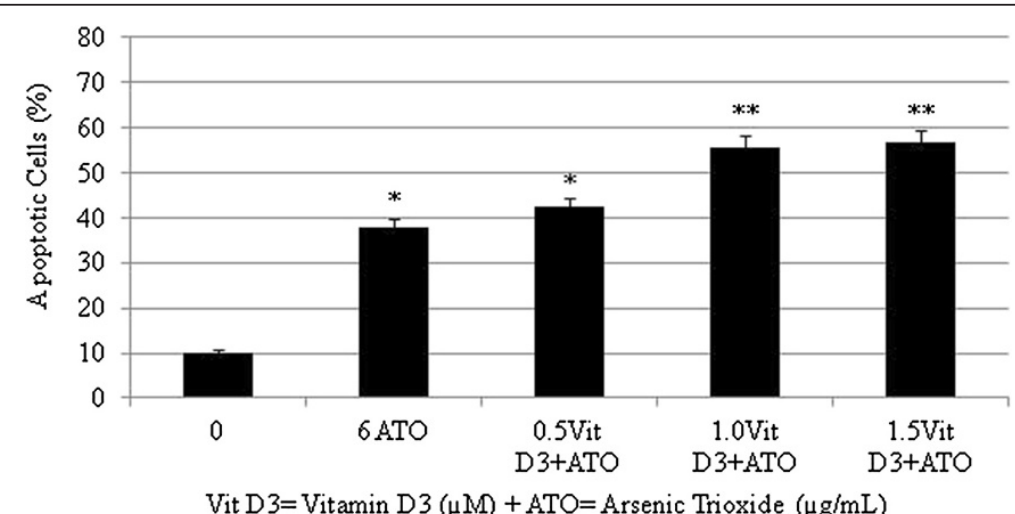

Figure 5 Annexin V-FITC positive cells induced by either arsenic trioxide alone or vitamin D3 and arsenic trioxide combination in HL-60 cells. Each point represents the mean value and the standard deviation of three experiments, showing similar results. *Significantly different from control $(0 \mu \mathrm{g} / \mathrm{mL}), \mathrm{p}<0.05$. 


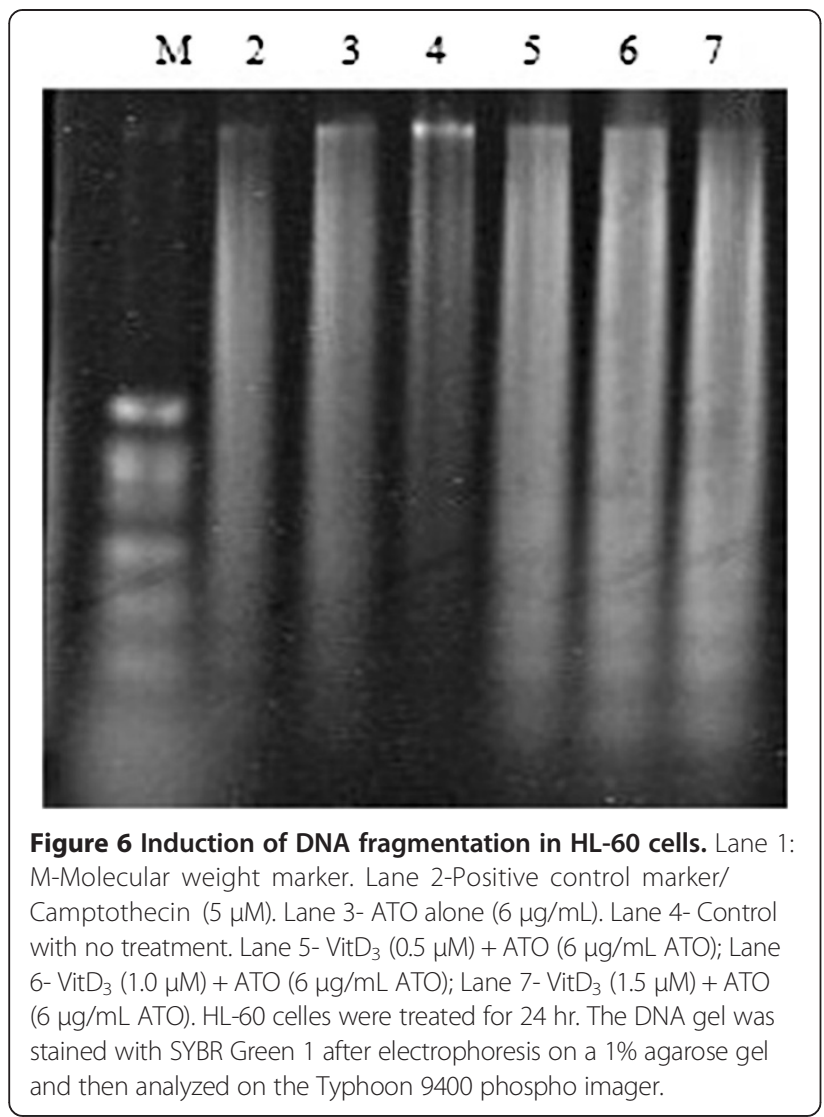

To test the hypothesis that Vit $\mathrm{D}_{3}$ potentiation of ATO toxicity in cancer cells may be mediated via apoptosis, we assessed annexin V FITC/PI staining using the flow cytometry analysis. The flow cytometry data show a significant increase in annexin $\mathrm{V}$ positive cells (apoptotic cells) in Vit $\mathrm{D}_{3}$ co-treated cells with ATO compared to ATO alone (Figures 3 and 4). The percentage of annexin $\mathrm{V}$ cells positive was $38 \pm 5 \%$ in cells treated with $6 \mu \mathrm{g} / \mathrm{mL}$ ATO and $57 \pm 6 \%$ in those treated with $1.5 \mu \mathrm{M}$ AA plus $6 \mu \mathrm{g} / \mathrm{mL}$ ATO with $\mathrm{p}<0.05$. By the means of flow cytometry, we report for the second time in our laboratory that antioxidant agents including ascorbic acid and Vit $\mathrm{D}_{3}$ potentiate the activity of ATO in cancer cells via phosphatidylserine externalization as result of the loss of membrane integrity, a major characteristic of cell death by apoptosis [10].

To confirm the apoptotic mechanism of Vit $\mathrm{D}_{3}$ on ATO, we further examined the apoptotic response, as judged by the appearance of a DNA ladder. A characteristic pattern of nucleosomal DNA fragmentation, which is the hallmark of apoptosis, was detected in ATOtreated cells alone and in Vit $\mathrm{D}_{3}$ plus ATO-treated cells (Figure 5). As seen in the dose-response experiment of the present study, the extent of DNA fragmentation increased proportionately with increasing doses of Vit $\mathrm{D}_{3}$, suggestive that Vit $\mathrm{D}_{3}$ potentiates ATO-induced apoptosis in HL-60 cells in a dose-dependent manner. Apoptosis usually is defined as programmed cell death and is characterized by specific morphologic features including cytoplasmic shrinkage, chromatin condensation, membrane blebbing, endonucleolytic degradation of genomic DNA, and the formation of apoptotic bodies [25,26]. There is evidence that apoptosis plays a role in the response of leukemia patients to chemotherapy, and there is probably an association between therapy-induced apoptosis and therapeutic efficacy $[27,28]$.

Both the flow cytometry assessment and DNA laddering assay clearly demonstrated that co-administration of Vit $\mathrm{D}_{3}$ potentiated the apoptotic effects in ATO-treated HL-60 cells. Thus, confirming the enabling ability of Vit $\mathrm{D}_{3}$ on ATO. Although the mechanism by which Vit $\mathrm{D}_{3}$ enhances ATO-mediated cytotoxicity in HL-60 cells remains unknown, here we provided clear evidence that Vit $\mathrm{D}_{3}$ potentiates the antitumor effects of ATO, and this potentiation is mediated at least in part, via activation of phosphatidylserine externalization and nucleosomal DNA fragmentation.

\section{Conclusion}

Given all the above, it is reasonable to infer that low doses of Vit $\mathrm{D}_{3}$ do not significantly affect cell viability in vitro while high doses of this compound are moderately toxic to HL-60 cells. We explore the cytotoxic and apoptotic effects of low doses of $\mathrm{Vit}^{\mathrm{D}} \mathrm{D}_{3}$ on the activity of ATO in human leukemia cells. The results of the MTT assay indicated that low doses of Vit $\mathrm{D}_{3}$ treatment significantly increase ATO toxicity in HL-60 cells in a dose dependent manner compared to ATO alone. This is most probably due to the different mechanisms through which both Vit $\mathrm{D}_{3}$ and ATO kill HL-60 cells. While testing the apoptotic mechanisms of these two compounds, both the flow cytometry assessment and DNA laddering evaluation showed an increase apoptotic cell death in cells co-treated with Vit $\mathrm{D}_{3}$ plus ATO compared to ATO alone, suggesting that $\mathrm{Vit} \mathrm{D}_{3}$ acts as pro-oxidant in the presence of ATO. Given the recent therapeutic progress in the treatment of APL with ATO (Trisenox), we believe that the combination of Vit $\mathrm{D}_{3}$ plus ATO is a promising candidate for a novel therapeutic approach in the management of APL However further clinical trials are needed to confirm this finding.

\section{Methods}

\section{Chemicals and test media}

Arsenic trioxide, Lot No. 091419, CASRN 1327-53-3, MW 197.84, with an active ingredient of $100 \%$ (w/v) arsenic in $10 \%$ nitric acid was purchased from Fisher Scientific (Houston Texas). Vitamin D3, Lot No. 120M1635V was purchased from Sigma Aldrich (St. Louis, MO). Growth medium RPMI 1640 containing $1 \mathrm{mmol} / \mathrm{L} \mathrm{L}$ - 
glutamine and fetal bovine serum (FBS) were purchased from Gibco BRL products (Grand Island, NY). PenicillinStreptomycin, Lot No. 3000880, phosphate buffered saline (PBS-pH 7.4) Lot No. 3000892, and MTT assay kit Lot No. 3000800 were obtained from the American Type Culture Collection - ATCC (Manassas, VA). Annexin V-FITC Apoptosis Detection Kit Lot No. 42191 was purchased from BD Biosciences (San Diego, CA). Apoptotic DNALadder kit, Lot No. 11324200 was purchased from Roche Molecular Biochemicals (Indianapolis, IN).

\section{Cell culture}

The HL-60 promyelocytic leukemia cell line (No. CCL-240) was purchased from the American Type Culture CollectionATCC (Manassas, VA). This cell line has been derived from peripheral blood cells of a 36-year old Caucasian female with acute promyelocytic leukemia (APL). The HL60 cells grow as a suspension culture. In the laboratory, cells were stored in the liquid nitrogen until use. They were next thawed by gentle agitation of their containers (vials) for 2 minutes in a water bath at $37^{\circ} \mathrm{C}$. After thawing, the content of each vial of cell was transferred to a $100 \mathrm{~mm}$ tissue culture dish, diluted with up to $20 \mathrm{ml}$ of RPMI 1640 containing $1 \mathrm{mmol} / \mathrm{L}$ glutamine and supplemented with $10 \%(\mathrm{v} / \mathrm{v})$ fetal bovine serum (FBS), and $1 \%$ $(\mathrm{w} / \mathrm{v})$ penicillin/streptomycin. The $100 \mathrm{~mm}$ culture dish, containing $2 \times 10^{6}$ viable cells, were observed under the microscope, followed by incubation in a humidified $5 \%$ $\mathrm{CO}_{2}$ incubator at $37^{\circ} \mathrm{C}$. Three times a week, they were diluted under same conditions to maintain a density of $5 \times 10^{5} / \mathrm{mL}$, and harvested in the exponential phase of growth.

\section{Treatment and measurement of cell viability}

To explore the effect of vitamin $\left(V_{i t} \mathrm{D}_{3}\right)$ on the viability of HL-60 cells, $1 \mathrm{ml}$ aliquots of cell suspension were transferred into 24 well tissue culture plates and treated with $1000 \mu \mathrm{M}$ of Vit $\mathrm{D}_{3}$ diluted to reach final doses of .78, 1.56, 3.12, 6.25,12.5, and $25 \mu \mathrm{M}$ cholecalciferol. Cells were placed in the humidified $5 \% \mathrm{CO}_{2}$ incubator at $37^{\circ} \mathrm{C}$ for $24 \mathrm{hr}$. Cells incubated in culture medium alone served as a control (untreated wells). After incubation, $200 \mu \mathrm{L}$ aliquots of MTT solution were added to each well and re-incubated for $30 \mathrm{~min}$ at $37^{\circ} \mathrm{C}$, followed by low centrifugation at $800 \mathrm{rpm}$ for $5 \mathrm{~min}$. The supernatants were carefully aspirated and $200 \mu \mathrm{L}$ aliquots of dimethylsulfoxide (DMSO) were added to each well to dissolve the formazan crystals, followed by incubation for $10 \mathrm{~min}$ to dissolve air bubbles. The culture plates were placed on a Multiskan micro-plate reader and the absorbance was measured at $570 \mathrm{~nm}$. The amount of color produced is directly proportional to the number of viable cells. All assays were performed in three replicates for each, Vit $\mathrm{D}_{3}$, ATO, or Vit $\mathrm{D}_{3}+$
ATO concentration, and means $\pm \mathrm{SD}$ values were calculated. Cell viability rate was calculated as the percentage of MTT absorption as follows: \% survival = (mean experimental absorbance/mean control absorbance) $\times 100$. In a recently published experiment, we reported that ATO is cytotoxic to HL-60 cells, showing a $24 \mathrm{hr} \mathrm{LD}_{50}$ of $6.4 \pm 0.6 \mu \mathrm{g} / \mathrm{mL}$ [14]. Hence, to examine the effect of Vit $\mathrm{D}_{3}$ on ATO-induced cytotoxicity, cells were exposed to $0.5,1.0$ and $1.50 \mu \mathrm{M}$ of $\mathrm{VitD}_{3}$ for $30 \mathrm{~min}$ and then co-exposed to $6 \mu \mathrm{g} / \mathrm{mL}$ ATO and incubated in humidified $5 \% \mathrm{CO}_{2}$ incubator at $37^{\circ} \mathrm{C}$ for $24 \mathrm{hr}$, and tested for cell viability following the MTT assay protocol as described above.

\section{Flow cytometric analysis of phosphatidylserine externalization}

The ability of cells to actively undergo apoptosis depends on their characteristic to lose membrane asymmetry in early phases of the apoptosis process. This early marker of programmed cell death is determined by analyzing phosphatidylserine (PS) translocation from the inner compartment of the plasma membrane to the outer compartment, thereby exposing PS to the external environment. Since Annexin V has a high affinity for PS it is effectively used in identifying apoptotic cells. Propidium iodide (PI) is a standard cytometric viability probe and is used to differentiate viable from nonviable cells. Viable cells with intact membranes exclude PI, whereas the membranes of dead and damaged cells are permeable to PI. HL-60 cells were double stained with a FITCconjugated Annexin V antibody and PI $(1 \mu \mathrm{g} / \mathrm{mL})$ BD Biosciences (San Diego, CA) and analyzed by flow cytometry (FACSCalibur and Cell Quest Pro Software, BD Biosciences, San Diego, CA). HL-60 cells were treated with low doses of Vit $D_{3}$ for $30 \mathrm{~min}$ prior and then treated with $6 \mu \mathrm{g} / \mathrm{mL}$ ATO for 24 hours. After treatment, $1 \times 10^{6}$ cells/mL were washed with cold PBS and then resuspended in $1 \mathrm{X}$ binding buffer. One hundred (100) $\mu \mathrm{L}$ of the solution was transferred to a culture tube where $5 \mu \mathrm{L}$ of both Annexin V-FITC and PI were added. The solution was mixed and then incubated for $15 \mathrm{~min}$ at room temperature in the dark. An additional $400 \mu \mathrm{L}$ of $1 \mathrm{X}$ binding buffer was added to each tube and flow cytometric analysis was performed within $30 \mathrm{~min}$ of staining. A histogram analysis acquiring 10,000 events using M1 and M2 gates demonstrated viable cells versus nonviable cells. Results were analyzed and statistical analysis done using the Cell Quest Pro software BD Biosciences.

\section{Apoptosis DNA laddering assay}

The purification of total DNA from HL-60 cells exposed to ATO alone and ATO + Vit D3 was done and DNA fragmentation analysis was performed to confirm the 
apoptotic mechanism as evidenced by DNA laddering, the hallmark of apoptotic cells. The apoptotic DNA Ladder kit from Roche Molecular Biochemicals (Indianapolis, IN) was used as directed. A sample volume of $800 \mu \mathrm{L}$ containing $2 \times 10^{6}$ cells was combined with binding buffer and incubated for $10 \mathrm{~min}$ at room temperature. Isopropanol was added to the sample and vortex. The sample mixture was added to the upper reservoir of the filter tube and centrifuged for $1 \mathrm{~min}$ at $8,000 \mathrm{rpm}$. The flow through was discarded and $500 \mu \mathrm{L}$ of washing buffer was added to the upper reservoir and centrifuged for 1 minute at $8,000 \mathrm{rpm}$. The flow through was discarded and a final centrifugation was performed for $10 \mathrm{sec}$ at $13,000 \mathrm{rpm}$ to remove residual wash buffer. The filter tube was inserted into a clean $1.5 \mathrm{~mL}$ tube. The DNA was extracted by adding $800 \mu \mathrm{l}$ of elution buffer and centrifuge for $1 \mathrm{~min}$ at $8,000 \mathrm{rpm}$. A higher dilution volume was used to increase the elution efficiency. Total DNA was measured by removing $1 \mu \mathrm{L}$ from each sample and adding it to $999 \mu \mathrm{L}$ of distilled $\mathrm{H}_{2} \mathrm{O}$ and reading the absorbance on a spectrophotometer. The optical density (OD) reading was multiplied by $50 \mu \mathrm{g} / \mathrm{ml}$ and the amount of DNA needed to add to the agarose gel was calculated to be $3 \mu \mathrm{L}$ for each sample. The agarose gels were run in TBE (Tris-borate EDTA) buffer at 75 volts until the marker migrated to approximately $2 \mathrm{~cm}$ above the end of the chamber. The gel was stained with SYBR Green 1 for 24 hours and analyzed on the Typhoon 9400 phospho imager from GE Healthcare (Piscataway, NJ).

\section{Statistical analysis}

Experiments were performed in triplicates. Data were presented as means \pm SDs. Where appropriate, one-way ANOVA or student paired $t$-test was performed using SAS Software available in the Biostatistics Core Laboratory at Jackson State University. P-values less than 0.05 were considered statistically significant.

\section{Abbreviations}

ANOVA: One way analysis of variance; APL: Acute promyelocytic leukemia; ATO: Arsenic rioxide; DMSO: Dimethylsulfoxide; DNA: Deoxyribonucleic acid; FACS: Fluorescence activated cell sorting system; MTT: 3-(4,5-dimethyl-2thiazolyl)-2,5-diphenyl-2H-tetrazolium bromide; PS: Phosphatidylserine; Vit $D_{3}$ : Vitamin $D_{3}$.

\section{Competing interests}

The authors declare that they have no competing interests.

\section{Authors' contributions}

$\mathrm{CR}$ and $\mathrm{CY}$ have performed the experiment and drafted the manuscript that was reviewed by all authors. CY and DS have assisted in performing the statistical analysis and data interpretation. P T has supervised the experiment and reviewed the manuscript for submission. All authors have read and approved the final draft of the manuscript.

\section{Acknowledgements}

The research described in this publication was made possible by a grant from the National Institutes of Health (Grant No. 2G12RR013459, and NIH-NIMHD Grant No. 8G12MD007581) at Jackson State University. C Rogers has presented this work at the 2012 American Association for Cancer Research (AACR) Annual Meeting. A poster presentation on this manuscript was presented at the $9^{\text {th }}$ International Symposium on Recent Advances in Environmental Health Research at Jackson State University in September $16-19,2012$

Received: 18 February 2014 Accepted: 16 March 2014 Published: 25 March 2014

\section{References}

1. Soignet SL, Maslak P, Wang ZG, Jhanwar S, Calleja E, Dardashti LJ, Corso D, DeBlasio A, Gabrilove J, Scheinberg DA, Pandolfi PP, Warrell RP: Complete remission after treatment of acute promyelocytic leukemia with arsenic trioxide. N Engl J Med 1998, 339:1341-1348.

2. Soignet SL, Frankel SR, Douer D, Tallman MS, Kantarjian H, Calleja E, Stone RM, Kalaycio M, Scheinberg DA, Steinherz P, Sievers EL, Coutré S, Dahllberg S, Ellison R, Warrell RP Jr: United States multicenter study of arsenic trioxide in relapsed acute promyelocytic leukemia. J Clin Oncol 2001, 19:3852-3860.

3. Chen GQ, Zhu J, Shi XG, Ni JN, Zhong HJ, Si GY, Jin XL, Tang W, Li XS, Xong SM, Shen ZX, Sun GL, Ma J, Zhang P, Zhang TD, Gazin C, Naoe T, Chen SJ, Wang $Z Y, C$ Chen $Z$ : In vitro studies on cellular and molecular mechanisms of arsenic trioxide (As2O3) in the treatment of acute promyelocytic leukemia: As2O3 induces NB4 cell apoptosis with downregulation of Bcl2 expression and modulation of PML-RAR/PML proteins. Blood 1996, 88:1052-1061.

4. Rousselot P, Labaume S, Marolleau JP, Larghero J, Noguera MH, Brouet JC, Fermand JP: Arsenic trioxide and melarsoprol induce apoptosis in plasma cell lines and in plasma cells from myeloma patients. Cancer Res 1999, 59:1041-1048

5. Shen L, Chen TX, Wang YP, Lin Z, Zhao HJ, Zu YZ, Wu G, Ying DM: Arsenic trioxide induced apoptosis of the human B lymphoma cell line MBC-1. J Biol Regulat Homeost Agent 2000, 14:116-119.

6. Wang QM, Jones JB, Studzinski GP: Cyclin-dependent kinase Inhibitor p27 as a mediator of the G1-S phase block induced by 1,25-dihydroxyvitamin D3 in HL60 cells. Cancer Res 1996, 56:264.

7. Chen YC, Lin-Shiau SY, Lin JK: Involvement of reactive oxygen species and caspase 3 activation in arsenite-induced apoptosis. J Cell Physiol 1998, 177:324-333.

8. Jing Y, Dai J, Chalmers-Redman RM, Tatton WG, Waxman S: Arsenic trioxide selectively induces acute promyelocytic leukemia cell apoptosis via a hydrogen peroxide-dependent pathway. Blood 1999, 94:2102-2111.

9. Huang HS, Chang WC, Chen CJ: Involvement of reactive oxygen species in arsenite-induced downregulation of phospholipid hydroperoxide glutathione peroxidase in human epidermoid carcinoma A431 cells. Free Radic Biol Med 2002, 33:864-873.

10. Yedjou CG, Tchounwou PB: In vitro cytotoxic and genotoxic effects of arsenic trioxide on human leukemia ( $\mathrm{HL}-60)$ cells using the MTT and alkaline single cell gel electrophoresis (comet) assays. Mol Cell Biochem 2007, 301:123-130.

11. Mellanby E: An experimental investigation on rickets. Lancet 1919, 193(4985):407-412.

12. Napoli JL, Fivizzani MA, Schnoes HK, DeLuca HF: Synthesis of vitamin D5: its biological activity relative to D3 and D2. Arch Biochem Biophys 1979, 197:119-125.

13. Banach-Petrosky W, Ouyang X, Gao H, Nader K, Ji Y, Suh N, DiPaola RS, Abate-Shen C: Vitamin D inhibits the formation of prostatic intraepithelial neoplasia in Nkx3.1;Pten mutant mice. Clin Cancer Res 2006, 12:5895-5901.

14. Trump DL, Deeb K, Johnson CS: Vitamin D: Considerations in the continued development as an agent for cancer prevention and therapy. Cancer J 2010, 16(1):1-9.

15. Yedjou C, Tchounwou PB, Jenkins J, McMurray R: Basic mechanisms of arsenic trioxide (ATO)-induced apoptosis in human leukemia (HL-60). J. Hematol Oncol 2010, 3:28.

16. Thorne J, Campbell MJ: The vitamin D receptor in cancer. Proc Nutr Soc 2008, 67(2):115-127.

17. Moreno J, Krishnan AV, Feldman D: Molecular mechanisms mediating the antiproliferative effects of vitamin D in prostate cancer. J Steroid Biochem Mol Biol 2005, 97(1-2):31-36.

18. Deeb KK, Trump DL, Johnson CS: Vitamin D signalling pathways in cancer: potential for anticancer therapeutics. Nat Rev Cancer 2007, 7(9):684-700. 
19. Tchounwou PB, Yedjou CG, Dorsey WC: Arsenic trioxide induced transcriptional activation and expression of stress genes in human liver carcinoma cells (HepG2). Cellular and Molecular Biology ${ }^{\mathrm{TM}}$ 2003, 49(7):1071-1079.

20. Yedjou CG, Thuisseu LD, Tchounwou CK, Gomes M, Howard C, Tchounwou PB: Ascorbic acid potentiation of arsenic trioxide anticancer activity against acute promyelocytic leukemia. Archives of Drug Information 2009, 2(4):59-65.

21. Norman AW, Roth J, Orci L: The vitamin D endocrine system: steroid metabolism, hormone receptors and biological response (calcium binding proteins). Endocr Rev 1982, 3:331-366

22. Henry HL, Norman AW: Vitamin D: metabolism and biological actions. Annu Rev Nutr 1984, 4:493-498.

23. Gysemans CA, Cardozo AK, Callewaert H: 1,25- Dihydroxyvitamin D3 modulates expression of chemokines and cytokines in pancreatic islets: implications for prevention of diabetes in nonobese diabetic mice. Endocrinology 1956-1964, 2005:146.

24. Abe E, Miyaura C, Sakagami H, Takeda M, Konno K, Yamazaki T, Yoshiki S, Suda T: Differentiation of mouse myeloid leukemia cells induced by 1,25-dihydroxyvitamin D3. In Proceedings of the National Academy of Sciences of the United States of America, Volume 78. 1981:4990-4994.

25. Wyllie AH: Apoptosis and carcinogenesis. Eur J Cell Biol 1997, 73:189.

26. Rudel T, Bokoch GM: Membrane and morphological changes in apoptotic cells regulated by caspase-mediated activation of PAK2. Science 1997, 276:1571.

27. Dive C, Evans CA, Whetton AD: Induction of apoptosis-new targets for cancer chemotherapy. Semin Cancer Biol 1992, 3:417.

28. Sachs L, Lotem J: Control of programmed cell death in normal and leukemic cells: new implications for therapy. Blood 1993, 82:15.

doi:10.1186/2162-3619-3-9

Cite this article as: Rogers et al.: Vitamin D3 potentiates the antitumorigenic effects of arsenic trioxide in human leukemia (HL-60) cells. Experimental Hematology \& Oncology 2014 3:9.

\section{Submit your next manuscript to BioMed Central and take full advantage of:}

- Convenient online submission

- Thorough peer review

- No space constraints or color figure charges

- Immediate publication on acceptance

- Inclusion in PubMed, CAS, Scopus and Google Scholar

- Research which is freely available for redistribution 